\title{
CONSUMER TRUST IN ONLINE PURCHASE DECISION
}

\author{
Febrina Mahliza \\ Faculty of Economics and Business \\ Universitas Mercu Buana \\ Jakarta, Indonesia
}

Article DOI: https://doi.org/10.36713/epra4022

\begin{abstract}
Trust plays an important role in online purchasing. Trust issues that arise in online purchasing occur since consumers cannot verify the product directly. This study aims to analyze the antecedents of trust in terms of online purchase decision and analyze the effect of trust on online purchase decision. The sampling technique used in this study was purposive sampling. The total sample of 120 respondents in Jakarta was obtained through the distribution of online questionnaires. The data analysis method used in this study is Partial Least Square (PLS). The results show that brand image and security are the antecedents of trust which have a significant positive effect on trust. The results show that perceived risk is the antecedent of trust which has a significant negative effect on trust. The results also show that consumer trust has a significant positive effect on online purchase decision.
\end{abstract}

KEYWORDS: trust, antecedents, purchase decision, partial least square

\section{INTRODUCTION}

Trust has always been an important factor in influencing consumer behavior towards companies (Schurr \& Ozanne, 1985). Trust plays an important role in e-commerce transactions because consumers will not shop online if they do not trust the seller (Kim, Ferrin, \& Rao, 2008). However, trust issues that arise in online purchasing occur since consumers cannot verify the product directly (Dachyar \& Banjarnahor, 2017).

Trust also becomes an issue that needs to be considered by the seller because it is related to consumers in making purchase decision (Murwatiningsih \& Apriliani, 2013). Consumers decide to purchase online because consumers feel that sellers can be trusted (Putra, Rochman, \& Noermijati, 2017). The higher trust will increase consumer purchase decision (Tanjung, Elfa, \& Andreas, 2018). Consumers who already trust a seller will be interested in making a purchase decision (Irawan, 2018). Trust is the essential element for building relationship with consumers (Mittal, 2013).

Since trust has an important role, it is important to identify the antecedent factors of trust that can increase or decrease trust. Furthermore, consumer trust with antecedent of trust will be seen its effect on online purchase decision. One of antecedents of trust is brand image. Brand image is one of the antecedents of trust which has a positive effect on trust (Prasetya,
Kumadji, \& Yulianto, 2014). The higher the brand image of seller, the higher trust by consumer.

The other antecedents of trust is security. Security is one of the antecedents of trust which has a positive effect on trust (Azam, Qiang, \& Abdullah, 2012; Hayuningtyas \& Widiyanto, 2015). The higher the sercurity provided by of seller, the higher trust by consumer.

The other antecedents of trust is perceived risk. Consumer trust in online purchasing is also influenced by the risk perceived by consumers (Murwatiningsih \& Apriliani, 2013). Consumers who concern about online transactions will lead them to choose sellers who successfully meet the requirements as trustworthy sellers (Hong, 2015). The lower the risk perceived by consumers, the higher the consumers trust in seller.

Based on the description above, this study aims to analyze the antecedents of trust including variable brand image, safety and perceived risk. Furthermore, this study aims to analyze the effect of consumer trust on online purchase decision. In this study, DKI Jakarta was chosen as the location of the study because in 2018, 80.4\% of the population of DKI Jakarta was internet users (Indonesia Internet Service Provider Association, 2018). 


\section{LITERATURE REVIEW Brand Image and Trust}

Brand image is a series of associations of a brand that is in the minds of consumers who are organized into a meaning (Aaker, 1994). Brand image is a collection of associations that exist in consumers' memories that are perceived and believed by consumers (Keller, 2013). Brand image is not only related to product image but can be related to company or seller's image (Rekarti, 2012).

Brand image is one of the antecedents of trust which has a positive effect on consumer trust (Prasetya et al., 2014). Brand image is measured through brand excellence, brand strength and brand uniqueness (Priskila, Sembiring, \& Mangani, 2016). Brand image makes the credibility and reputation which later becomes guideline for consumer (Wijaya, 2013). Brand image had strong effect on trust formation (Yeh \& Li, 2009). The higher the brand image of seller, the higher the trust by consumer.

\section{Security and Trust}

Consumers' perceptions of security, that is, consumers expect their personal information shared on the seller's site to not be seen, stored or manipulated by other parties (Chellappa \& Pavlou, 2002). Security is a key factor that people concerns about in using internet to purchase because most transactions are carried out on the web where information about users is transferred through an insecure environment (Raman \& Annamalai, 2011). Consumer will trust the seller when consumer feels that the seller provides security. Consumer trust is influenced by the security that provided by the sellers who handling their data (Flavián \& Guinalíu, 2006).

Security is one of the antecedents of trust which has a positive effect on consumer trust (Azam et al., 2012; Hayuningtyas \& Widiyanto, 2015). Security can be reflected through guarantees of transaction security and data confidentiality (Azam et al., 2012). The higher of security provided by seller, the higher consumer's trust (Kim, Ferrin, \& Rao, 2003). When the seller are able to increase security to consumer, consumer trust can be increased (Mittal, 2013).

\section{Perceived Risk and Trust}

Perceived risk is consumer perceptions of uncertainty and adverse consequences in carrying out an activity (Dowling \& Staelin, 1994). Perceived risk is the level of risk that is believed by consumers related to the purchase of a product from a particular seller (Miyazaki \& Fernandez, 2001). Perceived risk can be reflected through the risk about the suitability of product, the suitability of information, and privacy (Murwatiningsih \& Apriliani, 2013).

In the context of online commerce, perceived risk is considered higher than in traditional commerce because of the limited physical contact between consumers and products to be purchased. Consumer who concerns about online transactions will lead consumers to choose sellers who successfully meet the requirements as trustworthy sellers (Hong, 2015). The lower the perceived risk, the higher the consumer trust in seller.

\section{Trust and Purchase Decision}

Trust plays an important role in e-commerce transactions because consumers will not shop online if they do not trust the seller (Kim et al., 2008). Trust is the expectation of consumers towards sellers that they have appropriate behavior in fulfilling their commitments to consumers (Gefen, Karahanna, \& Straub, 2003). Trust is something that makes consumers decide to transact online because consumers feel that the seller can be trusted (Putra et al., 2017).

Trust is something that needs to be considered by the seller to consumers to obtain purchase decision (Murwatiningsih \& Apriliani, 2013). Purchase decision is a process of consumers in recognizing the problem, finding information about a particular product or brand, evaluating alternatives that further lead to purchasing decisions (Kotler \& Keller, 2012). Indicators of purchase decision include stability in purchasing, desire to repurchase, in accordance with the wishes (Hayuningtyas \& Widiyanto, 2015).

Consumers need trust that is reflected through integrity, benevolence and competence from sellers before they make a purchase decision (Budyastuti \& Iskandar, 2018; Hayuningtyas \& Widiyanto, 2015; Kwahk, Ge, \& Park, 2012; Rahmawati \& Widiyanto, 2013). With its antecedents, trust has a positive effect on consumer purchase decision (Hayuningtyas \& Widiyanto, 2015; Rahmawati \& Widiyanto, 2013). The higher of consumer trust in sellers, the higher of consumer purchase decision.

\section{HYPHOTESIS}

Based on the description above, the hypothesis formulated in this study are:

$\mathrm{H} 1=$ Brand image has a positive effect on trust.

$\mathrm{H} 2=$ Safety has a positive effect on trust.

H3 = Perceived risk has a negative effect on trust.

H4 = Trust has a positive effect on purchase decision.

Based on the hypothesis development, the framework of this study can be seen in Figure 1. 


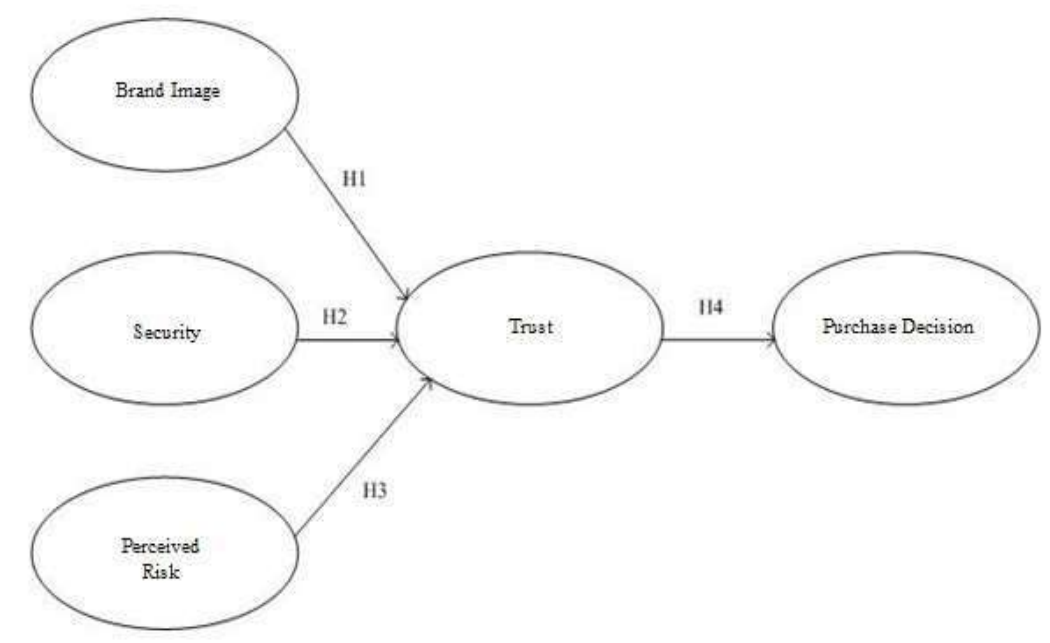

Figure 1. Framework

\section{RESEARCH METHODS}

This type of this research is causal research. The variables studied consisted of latent variables and indicators. The latent variables studied are brand image, security, perceived risk, trust and purchase decision. Measurement of variables can be seen in Table 1 .

Table 1. Measurement

\begin{tabular}{|c|c|c|}
\hline Constructs & Indicators & References \\
\hline Brand Image & $\begin{array}{ll}\text { - } & \text { Brand excellence (BI1) } \\
\text { - } & \text { Brand strength (BI2) } \\
\text { - } & \text { Brand uniqueness (BI3) } \\
\end{array}$ & (Priskila et al., 2016) \\
\hline Security & $\begin{array}{l}\text { - Transaction security guarantee (SC1) } \\
\text { - Data confidentiality (SC2) }\end{array}$ & (Azam et al., 2012) \\
\hline Perceived Risk & $\begin{array}{ll} & \text { The suitability of product (PR1) } \\
\text { - } & \text { The suitability of information (PR2) } \\
\text { - } & \text { Privacy (PR3) }\end{array}$ & $\begin{array}{l}\text { (Murwatiningsih \& Apriliani, } \\
\text { 2013) }\end{array}$ \\
\hline Trust & $\begin{array}{ll}\text { - } & \text { Competence of seller (TR1) } \\
\text { - } & \text { Benevolence of seller (TR2) } \\
\text { - } & \text { Integrity of seller (TR3) } \\
\end{array}$ & $\begin{array}{l}\text { (Hayuningtyas \& Widiyanto, } \\
\text { 2015; Rahmawati \& } \\
\text { Widiyanto, 2013) }\end{array}$ \\
\hline Purchase Decision & $\begin{array}{l}\text { - Stability in purchasing (KP1) } \\
\text { - } \text { Desire to repurchase (KP2) } \\
\text { - } \quad \text { In accordance with the wishes (KP3) }\end{array}$ & $\begin{array}{l}\text { (Hayuningtyas \& Widiyanto, } \\
\text { 2015) }\end{array}$ \\
\hline
\end{tabular}

This study used purposive sampling technique. The criteria of respondents i.e. consumers who live in Jakarta and have made an online purchase decision. The number of respondents in this study is 120 respondents.

Data collection was conducted in FebruaryApril 2019 through the distribution of online questionnaires with a Likert scale ranging from 1-5. The distributed questionnaire had already been tested for its level of validity and reliability through an instrument trial. Data were analyzed using a component based structural equation modeling (SEM) approach known as Partial Least Square (PLS).

\section{RESULTS AND DISCUSSION \\ Profile of Respondents}

Respondents are internet users who live in Jakarta and have made an online purchase decision. The respondents profile consists of demographic data on gender, age, occupation and income. Profile of respondents can be seen in Table 2 . 
EPRA International Journal of Multidisciplinary Research (IJMR) - Peer Reviewed Journal Volume: 6 | Issue: 2 | February 2020 || Journal DOI: 10.36713/epra2013 || SJIF Impact Factor: 5.614||ISI Value: 1.188

Table 2. Profile of Respondents

\begin{tabular}{cccc}
\hline Parameters & Items & Frequency & Persentage \\
\hline Gender & Male & 48 & $40 \%$ \\
& Female & 72 & $60 \%$ \\
\hline Age & $15-25$ years & 45 & $37.5 \%$ \\
& $26-36$ years & 56 & $46.7 \%$ \\
& $37-47$ years & 18 & $15 \%$ \\
& $>47$ years & 1 & $0.8 \%$ \\
\hline Occupation & Private employee & 109 & $90.8 \%$ \\
& Civil servant & 1 & $0.8 \%$ \\
& Entrepreneur & 7 & $5.8 \%$ \\
Income & Others & 3 & $2.5 \%$ \\
& $<$ Rp. 1.000 .000 & 6 & $5 \%$ \\
& Rp. $1.000 .001-$ Rp. 4.000 .000 & 21 & $17.5 \%$ \\
& Rp. 4.000.001 - Rp. 7.000.000 & 70 & $58.3 \%$ \\
& $>$ Rp. 7.000 .000 & 23 & $19.2 \%$
\end{tabular}

Source: Data Processed, 2019

Convergent validity is seen from the generated outer

Partial Least Square

\section{Evaluation of Measurement Model}

Evaluation of measurement models can be seen from the results of convergent validity. loading value. Indicator outer loading value greater than 0.7 is said to be valid. The outer loading value of this study can be seen in Table 2 .

Table 2. Outer Loading Values

\begin{tabular}{ccc}
\hline Variables & Indicators & Outer Loading \\
\hline Brand Image & BI1 & 0.715 \\
& BI2 & 0.767 \\
& BI3 & 0.823 \\
\hline Security & SC1 & 0.892 \\
& SC2 & 0.909 \\
\hline \multirow{2}{*}{ Perceived Risk } & PR1 & 0.938 \\
& PR2 & 0.836 \\
Trust & PR3 & 0.912 \\
\hline \multirow{2}{*}{ Purchase Decision } & TR1 & 0.845 \\
& TR2 & 0.877 \\
& TR3 & 0.835 \\
\hline
\end{tabular}

Source: Data Processed, 2019

Based on the Table 2, it can be seen that all indicator variables have an outer loading value greater than 0.7 . It means all indicator variables are valid. There are no indicator variables that must be removed.
The construct has good reliability if the Composite Realiability value $>0.7$, and the Cronbach's Alpha value $>0.6$. Construct has good validity if the AVE value is above 0.5 . The following Composite Reliability, Cronbach's Alpha, and AVE values can be seen in Table 3 . 
Table 3. Values of Composite Reliability, Cronbach's Alpha, AVE

\begin{tabular}{lccc}
\hline \multicolumn{1}{c}{ Constructs } & $\begin{array}{c}\text { Composite } \\
\text { Reliability }\end{array}$ & Cronbach's Alpha & $\begin{array}{c}\text { Average Variance } \\
\text { Extracted (AVE) }\end{array}$ \\
\hline Brand Image & 0.813 & 0.661 & 0.592 \\
Security & 0.896 & 0.768 & 0.811 \\
Trust & 0.889 & 0.812 & 0.727 \\
Purchase Decision & 0.890 & 0.815 & 0.731 \\
Perceived Risk & 0.924 & 0.876 & 0.803 \\
\hline
\end{tabular}

\section{Source: Data Processed, 2019}

Based on Table 3, all constructs are reliable. This is because all constructs have Composite Reliability values above 0.7 and Cronbach's Alpha values $>0.6$. Besides being reliable, all constructs are valid. This can be seen from all constructs that have AVE values above 0.5 .

The next construct validity test is evaluating discriminant validity by comparing the AVE square root values with correlations between constructs. If the AVE square value of each construct is greater than the correlation value between constructs and other constructs in the model, then it is said to have a good discriminant validity value. The comparison of AVE square root results with correlations between constructs can be seen through The Fornell-Larcker Criterium (Table 4).

Table 4. The Fornell-Larcker Criterium

\begin{tabular}{lccccc}
\hline & Brand Image & Security & Trust & $\begin{array}{l}\text { Purchase } \\
\text { Decision }\end{array}$ & Perceived Risk \\
\hline Brand Image & $\mathbf{0 . 7 6 9}$ & & & & \\
Security & 0.520 & $\mathbf{0 . 9 0 1}$ & & & \\
Trust & 0.670 & 0.507 & $\mathbf{0 . 8 5 3}$ & & \\
Purchase & 0.577 & 0.374 & 0.771 & $\mathbf{0 . 8 5 5}$ & \\
Decision & -0.349 & -0.250 & -0.527 & -0.550 & $\mathbf{0 . 8 9 6}$ \\
Perceived Risk & & & & & \\
Source: Data Processed, 2019 & & & & & \\
\hline
\end{tabular}

Table 4 shows the bold diagonal value is the AVE square root value while the other value is the correlation value between constructs. AVE square root values for brand image, security, trust, purchase decision and perceived risk are greater than the maximum correlation value with other constructs listed in the same row and column. This means that the discriminant validity fulfilled.

\section{Evaluation of Structural Model}

The evaluation of the structural model looks at the relationship between constructs and their significance value as indicated by the t-statistic or pvalue based on PLS output. The path coefficient can be seen in Table 5. The path coefficient that has a pvalue $<0.05$ (significance level of $5 \%$ ) is declared significant.

Table 5. Path Coefficient

\begin{tabular}{lcccc}
\hline \multicolumn{1}{c}{ Path } & Constructs Coefficient & T-Statistics & P-Value & Results \\
\hline Brand Image $\rightarrow$ Trust & 0.461 & 6.155 & 0.000 & Significant \\
Security $\rightarrow$ Trust & 0.188 & 2.152 & 0.016 & Significant \\
Perceived Risk $\rightarrow$ Trust & -0.319 & 3.787 & 0.000 & Significant \\
Trust $\rightarrow$ Purchase Decision & 0.771 & 18.447 & 0.000 & Significant \\
\hline
\end{tabular}

Source: Data Processed, 2019

(significance level of 5\%)

Based on Table 5, the relationship test between constructs shows that the construct of brand image has a positive effect on trust with a construct coefficient value of 0.461 and is significant because of the $p$ value $(0,000)<0.05$. The security construct has a positive effect on trust with a construct coefficient of 0.188 and is significant because the p-value $(0.016)$ $<0.05$. The perceived risk construct has a negative effect on trust with a construct coefficient of -0.319 and is significant because the p-value $(0,000)<0.05$.
The construct of trust has a positive effect on purchasing decisions with a construct coefficient of 0.771 and is significant because the p-value $(0,000)$ $<0.05$. The evaluation of the structural model is also done by looking at the value of R-Square. The RSquare value of trust is 0.572 . R-Square value of the purchase decision is equal to 0.594 


\section{The Effect of Brand Image on Trust}

Brand image has a positive effect on trust with a construct coefficient of 0.461 . The influence of brand image on trust proved significant because p-value $(0,000)<0.05$. This means that $\mathrm{H} 1$ is accepted. This shows that the online store brand image has been proven to influence consumer trust in the context of online commerce.

The brand image in this study is reflected through brand excellence, brand strength and brand uniqueness. Consumers feel that the brand of the company as the seller that is superior, strong and unique, influences their trust before making an online purchasing. The results of this study indicate that the brand image is proven to act as one of the antecedents of trust. Brand image has become the antecendent of trust which has the most influencing on trust.

The results of this study are supported by Prasetya et al. (2014) which shows that the better the brand image of the seller, the higher the consumers trust. With a good brand image, this will affect consumer trust. The seller also uses consumer trust in the brand image as a sales strategy.

\section{The Effect of Security on Trust}

Security has a positive effect on trust with a construct coefficient of 0.188 . The effect of security on trust proved significant because the p-value $(0.016)<0.05$. This means that $\mathrm{H} 2$ is received. This shows that security in online commerce transactions is proven to affect consumer trust.

Security in this study is reflected through guarantees of transaction security and data confidentiality. Consumers feel that the seller that provides security guarantees in transactions and maintain the confidentiality of consumer data, affects their trust before making online purchasing. The results of this study indicate that security is proven to play a role as an antecedent of trust.

The results of this study are supported by Azam et al. (2012) and Hayuningtyas \& Widiyanto (2015) who show that security has a positive effect on consumer trust in the context of online purchasing. The higher the security provided by the seller, the higher of consumer trust. When the seller are able to increase security to consumers, consumer trust can be increased.

\section{The Effect of Perceived Risk on Trust}

The perceived risk has a negative effect on trust with a construct coefficient of -0.319 . The effect of perceived risk on trust proved significant because the p-value $(0,000)<0.05$. This means that $\mathrm{H} 3$ is accepted. This shows that the risk perceived by consumers in the context of online commerce is proven to affect consumer trust.

The perceived risk in this study is reflected through the suitability of the product, the suitability of information and privacy. Consumers feel that having a product that is in line with expectations, information that is in accordance with reality and their privacy that can be maintained, affects their trust before making an online purchasing. The results of this study indicate that perceived risk is proven to act as one of the antecedents of trust.

The results of this study are supported by Murwatiningsih \& Apriliani, (2013) which shows that perceived risk has a negative effect on consumer trust in the context of online purchasing. The lower the risk perceived by consumer, the higher the consumer trust. Consumers who concern about the risks arising from online transactions will lead consumers to choose sellers who successfully meet the requirements as trustworthy sellers (Hong, 2015).

\section{The Effect of Trust on Purchase Decision}

Trust has a positive effect on purchase decision with a construct coefficient of 0.771 . The influence of trust on purchase decision proved significant because the $\mathrm{p}$-value $(0,000)<0.05$. This means that $\mathrm{H} 4$ is accepted. This shows that consumer trust has been proven to influence purchase decision in the context of online commerce.

Trust in this study is reflected through the competence, benevolence and integrity of the seller (Budyastuti \& Iskandar, 2018; Hayuningtyas \& Widiyanto, 2015; Kwahk et al., 2012; Rahmawati \& Widiyanto, 2013). Consumers need trust that is reflected through integrity, benevolence and competence from sellers before they make a purchase decision. Consumers who feel that the seller is competent, provide good service to consumers and can be trusted, it can influence them to make purchase decisions.

The results of this study indicate that trust is proven to play a role as a mediating variable of the three antecedents of trust consisting of brand image, security and perceived risk to purchasing decisions. The results of this study are supported by Hayuningtyas \& Widiyanto (2015) and Rahmawati \& Widiyanto (2013) which shows that trust as a mediating variable of antecedents of trust, has a positive effect on purchasing decisions. The higher the consumer trust in sellers, the higher the consumer purchase decision.

\section{CONCLUSION AND IMPLICATION Conclusion}

Brand image has been proven to play a role as an antecedent of trust. Seller's brand image has a positive effect on consumer trust before they make online purchasing. The better the brand image of seller, which is reflected through brand excellence, brand strength and brand uniqueness, the higher the consumers trust.

Security is proven to play a role as an antecedent of trust. Security positively influences consumer trust before they make online purchasing. 
The higher the security provided by the seller, which is reflected through guaranteed security of transactions and data confidentiality, the higher the consumer trust.

The perceived risk is proven to play a role as an antecedent of trust. The perceived risk negatively affects consumer trust before they make an online purchase decision. The lower the risk perceived by consumers, which is reflected through the suitability of product, the suitability of information and maintained privacy, the higher the consumer trust.

Trust is proven to play a role as a mediating variable of the three antecedents of trust, which consists of brand image, security and perceived risk, towards purchasing decisions. Trust has a positive effect on purchase decision. The higher the consumer trust in seller, which is reflected through the competence, benevolence and integrity of seller, the higher the consumer purchase decision.

\section{Implication}

This study contributes to provide empirical evidence regarding consumer trust in the context of online purchasing where the trust issues that arise in online purchasing occur since consumers cannot verify the product directly. The results of this study can also be used as managerial implications on seller because the results show that consumer trust plays an important role in online purchase decision. Consumer trust can also be improved through antecedents variables. A seller that is able to increase consumer trust through trust antecedents (brand image, security and perceived risk), will subsequently have an impact on increasing consumer purchase decision.

This study has limitations in its scope. Therefore, the researcher can then add other constructs besides the constructs that have been used in this study. Further researchers can also add a larger number of samples and a wider area to be able to describe the situation in Indonesia.

\section{REFERENCES}

1. Aaker, D. A. (1994). Building a Brand: The Saturn Story. California Management Review, 36(2), 114-133.

2. Azam, A., Qiang, F., \& Abdullah, M. I. (2012). Consumers' E-commerce acceptance model: Antecedents of trust and satisfaction constructs. BEIAC 2012 - 2012 IEEE Business, Engineering and Industrial Applications Colloquium, 371376.

https://doi.org/10.1109/BEIAC.2012.6226086

3. Budyastuti, T., \& Iskandar, D. (2018). The Influence of Usefulness, Easy of Use and Trust Using E-Commerce To User Behaviour ( Case Study To Lazada . Com Consumers ). Journal of Marketing and Consumer Research, 46, 78-83.

4. Chellappa, R. K., \& Pavlou, P. A. (2002). Perceived information security, financial liability and consumer trust in electronic commerce transactions. Logistics Information Management,
15(5/6), 358-368

5. Dachyar, M., \& Banjarnahor, L. (2017). Factors influencing purchase intention towards consumerto-consumer e-commerce. Intangible Capital, 13(5), 946-966.

6. Dowling, G. R., \& Staelin, R. (1994). A Model of Perceived Risk and Intended Risk-handling Activity. Journal of Consumer Research, 21(1), 119-134.

7. Flavián, C., \& Guinalíu, M. (2006). Consumer trust, perceived security and privacy policy: Three basic elements of loyalty to a web site. Industrial Management \& Data Systems, 106(5), 601-620.

8. Gefen, D., Karahanna, E., \& Straub, D. W. (2003). Trust and TAM in Online Shopping: An Integrated Model Trust and TAM in Online Shopping: an Integrated Model. Source: MIS Quarterly MIS Quarterly, 27(1), 51-90.

9. Hayuningtyas, W. H., \& Widiyanto, I. (2015). Antecedent kepercayaan dan keputusan pembelian. Diponegoro Journal of Management, 4(4), $1-11$

10. Hong, I. B. (2015). International Journal of Information Management Understanding the consumer' $s$ online merchant selection process : The roles of product involvement, perceived risk , and trust expectation. International Journal of Information Management, 35(3), 322-336.

11. Indonesia Internet Service Provider Association. (2018). Penetrasi \& Profil Perilaku Pengguna Internet Indonesia. In Laporan Survei. Retrieved from $w$ ww.apjii.or.id

12. Irawan, I. A. (2018). Effect of trust, convinience, security and quality of service on online purchase decision (consumer case study in tangerang selatan area). Jurnal Ekonomi, 23(1), 114-122.

13. Keller, K. L. (2013). Strategic Brand Management: Building, Measuring, and Managing Brand Equity (4e Global). Harlow: Pearson Education Limited.

14. Kim, D. J., Ferrin, D. L., \& Rao, H. R. (2008). A trust-based consumer decision-making model in electronic commerce: The role of trust, perceived risk, and their antecedents. Decision Support Systems, 44(2), 544-564.

15. Kim, D. J., Ferrin, D. L., \& Rao, R. H. (2003). Antecedents of Consumer Trust in B-to-C Electronic Commerce. AMCIS 2003 Proceedings, (2003), 157-167.

16. Kotler, P., \& Keller, K. L. (2012). Marketing Management, 14th ed. New Jersey: Pearson Education, Inc.

17. Kwahk, K., Ge, X., \& Park, J. (2012). Investigating the Determinants of Purchase Intention in C2C E-Commerce. International Journal of Social, Behavioral, Educational, Economic, Business and Industrial Engineering, 6(9), 497-501.

18. Mittal, A. (2013). E-commerce: It's impact on consumer behavior. Global Journal of Management and Business Studies, 3(2), 131138.

19. Miyazaki, A. D., \& Fernandez. (2001). Consumer Perceptions of Privacy and Security Risks for 
Online Shopping. The Journal of Consumer Affairs, 35(1), 27-44.

20. Murwatiningsih, \& Apriliani, E. P. (2013). Apakah kepercayaan konsumen lebih efektif daripada risiko dan harga? Jurnal Dinamika Manajemen, 4(2), 184-191.

21. Prasetya, C. H. A., Kumadji, S., \& Yulianto, E. (2014). ( Survei pada Pembeli Sepeda Motor Honda Vario pada PT Sumber Purnama Sakti di Kabupaten Gresik ). Jurnal Administrasi Bisnis, 15(2).

22. Priskila, E. K., Sembiring, C. F., \& Mangani, K. S. (2016). Analisis keputusan pembelian di Tokopedia yang dipengaruhi celebrity endorser, brand image, kelompok referensi dan usia. Fundamental Management Journal, 9220(1), 1119.

23. Putra, B. A. P. W., Rochman, F., \& Noermijati, N. (2017). the Effect of Trust, Risk, and Web Design on Consumer Intention By Means of Consumer Attitude To Purchase Online. Jurnal Aplikasi Manajemen, 15(3), 472-479.

24. Rahmawati, S. A., \& Widiyanto, I. (2013). Antecedent Keputusan Pembelian Online. Diponegoro Journal of Management, 2(2009), 1 11 .

25. Raman, A., \& Annamalai, V. (2011). Web Services and e-Shopping Decisions : A Study on Malaysian e-Consumer. 3rd International Conference on Wireless Information Networks \& Business Information System (WINBIS-2011), 8 13.

26. Rekarti, E. (2012). Pengetahuan dan Keterhubungan Merek dalam Mempengaruhi Pembelian Konsumen. Jurnal Enterpreneur (Manajemen Dan Bisnis), 11(Juli), 40-57.

27. Schurr, P. H., \& Ozanne, J. L. (1985). Influences on Exchange Processes: Buyers' Preconceptions of a Seller's Trustworthiness and Bargaining Toughness. Journal of Consumer Research, 11(4), 939.

28. Tanjung, $C$., Elfa, N., \& Andreas, Y. (2018). Analysis of Price Perception, Promotion, and Trust toward Decision Purchase on Online Site Tokopedia. 3(12), 386-389.

29. Wijaya, B. S. (2013). Dimensions of Brand Image: A Conceptual Review from the Perspective of Brand Communication. European Journal of Business and Management, 5(31), 5565 .

30. Yeh, Y. S., \& Li, Y. M. (2009). Building trust in m-commerce: Contributions from quality and satisfaction. Online Information Review, 33(6), 1066-1086. 